\title{
Phytopathology and Private Enterprise.
}

$\mathrm{I}$ most of the European countries, as is the case in England, the insect pests and fungus diseases of agricultural plants are dealt with by one phytopathological service, and in spite of the opposition to such a practice in America this union has been found to work satisfactorily, for if at times one branch may seem to be profiting at the expense of the other, the two have so much in common that it is probably the most logical system to adopt. As we in Great Britain are more or less interested in what is happening in the corresponding service on the continent, it may perbaps be opportune to give an account of the National French Phytopathological Congress held at Lyons on June $28-30$, which we had the pleasure of attending through the kindness of the promoters, the P.L.M. Railway.

The meetings, on account of the heavy programme, began at the somewhat early hour-for an Englishman-of 8.30 A.M. and continued until after 6 P.M. M. Mangin, the director of the Natural History Museum, Paris, acted as president, and M. Boret, the ex-Minister of Agriculture, and several other deputies honoured the Congress with their presence. Some five hundred persons accepted invitations, and most of the surrounding countries were represented. The subjects discussed comprised papers on various entomological and mycological problems, the disinfection of the soil, the value of colloids in spraying, the relation of birds and field-mice to agriculture, and proposals for the establishment of regional committees to assist in the war against what may be termed shortly the enemies of plants. In view of the large quantities of certain chemicals employed in this fight--on an average 50,00o tons of copper sulphate are used, for example, in a year, and about one-third of that is imported-and the consequent increase in price which such a demand creates, the need for finding fresh insecticides and fungicides was also discussed, while motions were passed dealing with the necessity of obtaining nicotine plentifully and readily and the need for some sort of guarantee of purity in those chemical preparations used by the grower. The latter question, it may be said in passing, has been receiving of late some consideration in this country. The exhibits of the various research stations-Paris, St. Genis-Laval, Montargis, Mentone, etc.-and of various firms, notably those of Vermorel and Truffaut, were very fine, while a practical demonstration of spraying apparatus at Ampuis completed the work of the Congress.

Hitherto it has been left to a government to maintain a phytopathological service, either directly or indirectly, though there are notable examples of the enterprise of private associations in establishing and running laboratories for the study of diseases of the particular crops in which they are interested. Amongst these the Hawaiian Sugar Planters' Association, the Colonial Sugar Refining Company, the Assam Tea Planters' Association, and the recently founded Ceylon Tea Planters' Research Institute may be mentioned, while on a smaller scale we have seen the establishment of works' laboratories by several private firms in Great Britain for the study of certain problems affecting their businesses, but this is a side of which people are in the main ignorant, and indeed there is little reason why they should be enlightened. The fostering of the agricultural industry by the P.L.M. Railway in the area covered by their system dates fairly far back. It has to be remembered that in northern France the carrying trade of the railways consists largely of coal, wheat, and beet, but in mid and southern France the railway derives most of its revenue from flowers, fruit, and vegetables. In 1877 , when Phylloxera threatened to wipe out the wine industry, the P.L.M. Railway recognised that its revenue was closely bound up in the prosperity of the vineyards and did its utmost to assist in the stamping out of this dread disease. The service instituted then served as a nucleus out of which has grown the present magnificent organisation, which as it exists to-day is almost entirely of post-war origin. It is quite distinct from the service maintained by the state, but in actual practice it works in conjunction with and is really supplementary to it.

That disease may seriously affect the returns of an industry we all know, though it is difficult to obtain definite figures. M. Raybaud, the chief inspector to the company, estimates the injury caused by insects and fungi throughout the globe at ro milliards of francs per annum, of which one milliard's worth is done in France. That the former figure is probably a very fair estimate the following data collected haphazardly from literature and reduced to a par value will show; the estimates are for limited areas in most cases and for prices prevailing before or during the War. The Hessian Fly is said to cost the U.S.A. $20,000,000 l$. every year ; in the State of Washington the Codling Moth injures apples to the tune of $800,000 l$., and in another State 400,oool.; Conotrachelus nemuphar, one of the British "scheduled" pests, injures peaches worth 400,00ol. in Georgia; leaf injury by insects to tobacco in Sumatra on 80 estates amounts to $750,000 \mathrm{l}$.; Helopeltis causes about 200,oool. loss every year in the Dutch East Indies; Phytalus smithi 33,400 . to sugar-cane in Barbados, and figures are not available for the loss it causes in Mauritius, where it is a much more serious pest; Bruchus pisorum causes damage of more than $200,000 l$. in one province of Canada alone; Thrips tabaci, to those crops it attacks in the U.S.A. $600,000 \%$.; Frit-fly in Britain in 1912 damaged $12,126,198$ bushels of wheat which, if we allow $\mathrm{I} b$. per quarter, is equivalent to more than $\mathrm{I}, 5 \mathrm{I} 5,000 \mathrm{l}$; the Brown and Gold Tail Moths have cost Pennsylvania and the neighbouring States 6,000,0ool. loss annually; Prosagrotis orthogonia caused injury valued at $600,000 l$. in Montana in 1920 ; Cylas formicarius, where it is established in the U.S.A., causes a loss of about $\mathrm{I}, 500,000 l$. ; Sitotroga cerealella in Pennsylvania alone 200,oool.; one scale insect (Saissetia oleae) takes an annual toll of $400,000 l$. from the Californian Citrus industry; and if we include grain pests, Ohio loses 200,00ol., Alabama from 800,00ol. to 2,000, oool., while Calandra oryzae alone caused a loss of about $2,000,000 l$. in the U.S.A. in I9I8, but this was a particularly bad year. Damage on the grand scale is seen in the case of the Cotton Boll Weevil, which costs the cotton growers of the U.S.A. 35,000,000l. in lint and 5,00o, oool. in seed, and the Pink Boll Worm, which is said to cause a loss of ro,ooo,oool. in Egypt. Then we have the more general estimates of $20,000,000 l$. for the injury to the forest and shade trees of the U.S.A., I, ooo,oool. to the agricultural products of British Guiana, I,350,00ol. to the maize industry in South Africa, 25,000,00ol. annual loss to the field crops in Canada, and a similar amount in Germany. A mycologist would probably be able to supply as astounding figures for the losses caused by fungi.

Satisfied as to the need, therefore, of keeping a watchful eye on the diseases of plants, the P.L.M Railway maintains a central agricultural service bureau which carries on a progressive educative policy amongst the growers in the region covered by 
its lines, providing them with the latest literature on every subject which may be of interest to them, arranges conferences and demonstrations at convenient centres to which large attendances are assured through free travelling facilities, visits to other countries to study the conditions prevailing there, and also provides free carriage on their system for chemicals and spraying apparatus. The conferences are not confined to university professors and researchers in phytopathology, but the chemist and physicist, the manufacturer and the engineer take their place beside the practical man. Lively discussions result from such a gathering of experts, and not unusually the grower is able to hold his own. We were particularly struck by the keenness of the grower in everything pertaining to spraying, and whatever may be the opinion prevailing in Great Britain as to its value, there can be no doubt that the French agriculturalist is a firm adherent to the practice.

The phytopathological is but one side of the work carried out by the P.L.M. Railway. Since I9I2 it has founded ${ }^{3} 8$ experimental nurseries for the training of the peasants, and also many school gardens, subsidised largely the research station at St. GenisLaval and the Insectary at Mentone, experimented with many varieties of strawberries, established a nursery for growing cypress for hedging, and distributed hundreds of thousands of plants free, fruit trees, vines, black currants, asparagus, artichokes, tomatoes, and osiers being the chief, but potatoes and winter vegetables have also received their share of attention. In addition pisciculture, viticulture, and sericulture owe much to the liberality and the encouragement of the Company. A huge organisation and a well-filled purse have always been behind these movements. What is the result to the Company? In I9 Io it carried $x 90,000$ tons of fruit and vegetables, in I 925 this had grown to $488,85^{\circ}$ tons, so that the results of its labours are reflected in the balance-sheet at the end of the year in such a way as to encourage the Company to continue in the work which they are doing with such conspicuous success. L.

\section{A British Expedition to the Sepik River, New Guinea.}

$\mathrm{A}^{\mathrm{N}}$ expedition has been planned and is now being of which is to penetrate to the central mountain chain of New Guinea and locate the head-waters of the Sepik River. There is at present a theory that a large lake lies between the Victor Emmanuel Range to the north and the Müller Range to the south, which feeds both the Sepik and the Fly Rivers. In I89I Sir William MacGregor reached a point on the Fly River in the territory of Papua at lat. $8^{\circ} \mathrm{I} \mathrm{I}^{\prime} \mathrm{S}$., long. $\mathrm{I}_{4} \mathrm{I}^{\circ} 54^{\prime} \mathrm{E}$., and of recent years a number of explorations of the head-waters of the Fly River have been carried out by officers in the Papuan service. In I9I3-I4 Dr. Behrman's expedition proceeded up the Sepik River in what is now mandated territory and the advance party reached lat. $8^{\circ} \mathrm{II}^{\prime} \mathrm{S}$., long. $141^{\circ} 36^{\prime} \mathrm{E}$. in the Victor Emmanuel Range, but failed to attain the objective of the expedition, the source of the river. A survey was made up to the point reached by the advance party.

The object of the present expedition will be not only to locate the source of the Sepik, but also to cross and survey the country lying between the headwaters of this river and those of the Fly. Geological, anthropological, zoological, and botanical observations will be made on the way, and if the objective is attained, should lead to results of great importance, as the higher and hitherto unexplored parts of the central mountain chain should produce much new and valuable material in each of these branches of science.

The expedition will proceed by launch to the highest possible point on the Sepik, where a base will be formed. From this the main party will proceed into the hills. Should they succeed in reaching the Fly, they will return down this river, the base party returning down the Sepik independently. The base party will be in communication with the authorities at Rabal by radio, and the main party will keep in touch with the base by means of a small transmitting set. A kinematograph outfit will also be carried.

The personnel of the expedition so far as arranged at present consists of Mr. V. A. C. Findlay, leader and agricultural and topographical surveyor; Mrs. Findlay, engineer, radio operator and photographer; Mr. A. J. Hill, engineer and radio operator; Mr. K. H. Henderson, zoological and botanical collector; Mr. W. S. Malcolm, anthropologist; and Mr. C. T. Teychenné, geological surveyor.

The expedition has received the approval of the Royal Geographical Society, the Royal Anthropological Institute, and the Committee for Anthropology of the University of Oxford. The expedition is being organised under the direction of a council of which Lord St. John of Bletso is president, and Mr. Henry Balfour, The Hon. Mr. H. A. Casson, and Dr. A. F. R. Wollaston, are members. At the recent meeting of the British Association at Oxford a committee was appointed to co-operate in the work of organisation. The estimated cost of the expedition is 6oool., and contingently on that amount being raised, the expedition will leave England in the autumn of 1927 .

\section{The Pelagic Young of the Cod. ${ }^{1}$}

\begin{abstract}
M R. MICHAEL GRAHAM and Mr. J. N. Carruthers have attempted to correlate the known distribution of the pelagic young of the cod with the theoretical distribution deduced from three factorsmarket statistics, wind records, and experiments with drift-bottles. The theoretical part is undertaken by Mr. Carruthers, the practical part, dealing with the actual catches of the young fishes, by Mr. Graham. In addition $\mathrm{Mr}$. H. H. Goodchild investigated the food of the fry from the same samples. Three questions

1 "The Distribution of Pelagic Stages of the Cod in the North Sea in r924 in Relation to the System of Currents," by Michael Graham 1924 in Relation to the System of Currents," by Michael Graham
and $\mathrm{J}$. N. Carruthers. With a section on "The Food of Pelagic Young Cod" by H. H. Goodchild, Fisheries Laboratory, Lowestoft. Ministry of Agriculture and Fisheries. Fishery Investigations, Series 2, vol. 8 , No. 6, r925. London: H.M.S.O.
\end{abstract}

NO. 2966, VOL. I I 8$]$ are involved in the present paper: First, to what extent the drift affects the pelagic fry in the North Sea; secondly, what is the distribution of the fry; and thirdly, what is the food of the young in the pelagic stage ? To answer these questions the market statistics were used to ascertain the spawning-grounds and times, the methods being justified by previous work of one of the authors in r924. A system of cruises was undertaken to fish for the larvæ and postlarvæ from these spawning-grounds outwards; experiments with drift-bottles were made and wind statistics consulted. The ascertained distribution was then compared with the theoretical distribution, and the results were found to be so much in agreement that the authors seem to be justified in their con- 